\title{
TĂNG MEN GAN Ở BỆNH NHÂN BASEDOW
}

Bùi Thị Tuyết Mai ${ }^{1}$, Vũ Bích $\mathrm{Nga}^{2}$

1. Bệnh viện Đại học Y Hà Nội;

2. Truờng Đại học Y Hà Nội

DOI: $10.47122 /$ vjde.2020.43.15

\section{ABSTRACT \\ Hepatic hyperfunction ingraves' diaese patients}

Grave's disease is a hyperfunction of the thyroid gland associated with diffuse goiter due to excessive secretion of thyroid hormones into the blood, the excessive excretion of the hormones Triiodothyronin (T3) and Tetraiodthyronon (T4) too much compared to the need that create thyroidtoxicity affects many organ systems including the cardiovascular system, gastrointestinal tract... Clinically, abnormal liver function tests are often observed in untreated hyperthyroidism patients. However, the prevalence reported varied between studies, ranging from $37 \%$ to $78 \%$. Until now, a number of factors are thought to contribute to liver dysfunction in hyperthyroidism. However, the association between indicators of thyroid function and liver damage remains controversial and data demonstrating biochemical factors or parameters contribute to liver function abnormalities due to Basedow causes are still limited.

Key words: hepatic hyperfunction, Grave's disease

\section{TÓM TẮT}

Basedow là bệnh cường chức năng tuyến giáp kết hợp với bướu giáp phì đại lan tỏa do tăng tiết quá nhiều hormon tuyến giáp vào trong máu, sự bài tiết quá nhiều hormon Triiodothyronin (T3) và Tetraiodthyronon (T4) quá mức so với nhu cầu của cơ thể gây ra tình trạng nhiễm độc hormon tuyến giáp ảnh hưởng đến nhiều hệ thống cơ quan bao gồm hệ thống tim mạch, đường tiêu hóa... Trên lâm sàng, thường quan sát thấy các bất thường về xét nghiệm chức năng gan ở bệnh nhân cường giáp chưa được điều trị. Tuy nhiên, tỷ lệ lưu hành báo cáo khác nhau giữa các nghiên cứu khác nhau, dao động từ $37 \%$ đến $78 \%$. Cho đến nay, một số yếu tố được cho là góp phần gây rối loạn chức năng gan trong bệnh cảnh cường giáp. Tuy nhiên, mối liên quan giữa các chỉ số chức năng tuyến giáp và tổn thương gan vẫn còn gây tranh cãi và các dữ liệu chứng minh các yếu tố hoặc các thông số sinh hóa góp phần gây ra các bất thường về chức năng gan do Basedow gây ra vẫn còn hạn chế.

Tù khóa: Tăng men gan, basedow

Chịu trách nhiệm chính: Vũ Bích Nga

Ngày nhận bài: 15/10/2020

Ngày phản biện khoa học: 04/11/2020

Ngày duyệt bài: 13/12/2020

Email: vubichnga116@gmail.com

Điện thoại: 0913544622

\section{1.ĐĂT VẤN Đî̀}

Basedow là bệnh cường chức năng tuyến giáp kết hợp với phì đại bướu giáp lan tỏa do tăng tiết quá nhiều hormon tuyến giáp vào trong máu, sự tăng tiết quá nhiều hormon gây rối loạn điều hòa nội môi và không thể kìm hãm được.

Bệnh Basedow là bệnh lý nội tiết thường gặp ở nước ta cũng như trên thế giới. Bệnh có thể gặp ở mọi lứa tuổi, tỷ lệ mắc ở nữ lớn hơn nam. Trên thế giới, tỷ lệ bệnh Basedow là 0,14\%[1]. Ở Việt Nam Basedow chiếm khoảng 2,6\% các bệnh nội khoa điều trị tại Bệnh viện Bạch Mai và chiếm $45,8 \%$ các bệnh nội tiết[2].

Bệnh nhân thường có bướu tuyến giáp phì đại lan tỏa, lồi mắttăng hoạt động chức năng, bài tiết quá nhiều hormon Triiodothyronin (T3)và Tetraiodthyronon (T4) quá mức so với nhu cầu của cơ thể gây ra tình trạng nhiễm độc hormontuyến giáp với những biểu hiện lâm sàng là các dấu hiệu cường giáp thường gặp như: mệt mỏi, hồi hộp đánh trống ngực, nhịp tim nhanh, hay ra mồ hôi, run đầu chi...

Bệnh Basedow được xếp vào loại bệnh có 
cơ chế tự miễn dịch, trong đó kháng thể kích thích tuyến giáp kích thích thụ thể TSH (TSHR) dẫn đến việc sản xuất quá nhiều hormone tuyến giáp và hiện tượng tăng sản lan tỏa tuyến giáp. Vai trò trung tâm của tự kháng thể kháng thụ thể TSH (TRAb) trong cơ chế bệnh sinh của bệnh Basedow đã được công nhận trong nhiều thập kỷ. Ngoài tuyến giáp, TSHR còn được thấy rộng rãi trong nhiều loại mô ngoại biên như thùy trước tuyến yên, vùng dưới đồi, buồng trứng, tinh hoàn, da, thận, hệ thống miễn dịch, tủy xương, tế bào máu ngoại biên, mô mỡ, mô hốc mắt, nguyên bào sợi và xương. Tuy nhiên, tầm quan trọng trong vai trò sinh lý của chúng ở nhiều trường hợp vẫn là một chủ đề còn chưa rõ. Gần đây, người ta đã chứng minh rằng TSHR cũng tồn tại và hoạt động trong tế bào gan, bởi vì TSHR mRNA và sự xuất hiện protein này đã được tìm thấy trong tế bào gan, và $\mathrm{TSH}$ và globulin miễn dịch từ huyết thanh bò của bệnh nhân có tăng men gan (HDF) và nhóm chức năng gan bình thường (NHF) có liên quan theo giá trị sinh hóa của gan [17], [18].

Cường giáp là một trong những nguyên nhân gây nhiễm độc giáp, xảy ra ở khoảng $2 \%$ phụ nữ và $0,2 \%$ nam giới trên toàn thế giới và có thể ảnh hưởng đến nhiều hệ thống cơ quan bao gồm hệ thống tim mạch, đường tiêu hóa và gan. Bệnh Basedow là nguyên nhân phổ biến nhất gây hội chứng cường giáp và chiếm tới $50 \%$ - $80 \%$ các trường hợp mắc bệnh cường giáp ở các khu vực khác nhau trên thế giới[3]. Trên lâm sàng, thường quan sát thấy các bất thường về xét nghiệm chức năng gan ở bệnh nhân cường giáp không được điều trị. Tuy nhiên, tỷ lệ lưu hành báo cáo khác nhau giữa các nghiên cứu khác nhau, dao động từ $37 \%$ dến $78 \%$ [4], [5],[6],[7],[8], [9]. Có một số yếu tố đã được cho là góp phần gây rối loạn chức năng gan trong bệnh cảnh cường giáp, trong đó bệnh cường giáp đơn thuần được cho là phổ biến [10],[11],[12].

Về mặt cơ chế, một số nhà nghiên cứu cho rằng nồng độ triiodothyronine (T3) tăng cao gây ra rối loạn chức năng gan bằng cách gây ra tình trạng chết theo trương trình thông qua kích hoạt một con đường phụ thuộc ty lạp thể do cường giáp gây ra[13],[14]. Gần đây, một nghiên cứu của He và cộng sự đã chứng minh rằng nồng độ $\mathrm{TRAb}$ tăng cao có thể góp phần gây ra rối loạn chức năng gan ở bệnh nhân mắc Basedow. Tuy nhiên trong các nghiên cứu này, mối liên quan giữa các chỉ số chức năng tuyến giáp và tổn thương gan vẫn còn gây tranh cãi [4]. Cho đến nay, các dữ liệu chứng minh các yếu tố hoặc các thông số sinh hóa góp phần gây ra các bất thường về chức năng gan do Basedow gây ra vẫn còn hạn chế.

Trong quá trình khám và điều trị bệnh nhân Basedow, chúng tôi nhận thấy tần suất xuất hiện các bất thường về chức năng gan ở những bệnh nhân mắc Basedow mới được chẩn đoán và chưa được điều trị là khá phổ biến. Tuy nhiên, cơ chế bệnh sinh của nó hiện còn chưa được hiểu đầy đủ. Bài viết này nhằm mục đích cập nhật, tìm hiểu và làm rõ hơn về vấn đề tăng men gan ở bệnh nhân Basedow chưa được điều trị.

\section{CƠ CHẾ BÊ̂NH SINH CỦA BÊ̂NH BASEDOW}

Từ khi phát hiện ra bệnh Basedow cho tới nay đã có nhiều nghiên cứu và giả thuyết về cơ chế bệnh sinh của bệnh Basedow. Đa số các tác giả đều cho rằng đây là một rối loạn tự miễn dịch cơ quan đặc hiệu với sự xuất hiện của kháng thể kháng thụ thể tiếp nhận TSH.

Sự tương tác giữa các yếu tố môi trường như stress, nhiễm trùng, chấn thương... có thể gây giảm số lượng và chức năng tế bào lympho $\mathrm{T}$ ức chế. Hiện tượng này kêt hợp với sự thiếu hụt tế bào lympho T ức chế đặc hiệu tổ chức sẽ dẫn đến sự giảm khả năng ức chế đối với quần thể lympho $\mathrm{T}$ hỗ trợ. Những tế bào lympho $\mathrm{T}$ hỗ trợ đặc hiệu này khi có mặt của những tế bào mono và kháng nguyên đặc hiệu sẽ tác động kích thích các tế bào lympho $\mathrm{B}$ sản xuất ra kháng thể kháng lại thụ thể của TSH tại màng đáy tế bào tuyến giáp hay còn gọi là TRAb.

Kháng thể kích thích thụ thể của TSH (Thyrotropin Receptor Stimulating Antibody: TRSAb) hay còn gọi là kháng thể kích thích 
tuyến giáp TSI (thyroid stimulating immunoglobulins) bản chất là một imunoglobulin $\mathrm{G}(\mathrm{Ig} G)$.

TRSAb gắn cạnh tranh với $\mathrm{TSH}$ vào receptor của TSH tại màng tế bào tuyến giáp kích thích tuyến giáp tăng sinh tế bào, tăng kích thước tế bào, tăng sinh mạch máu, tăng tưới máu và tăng hoạt động chức năng của tế bào, hậu quả là kích thích liên tục tế bào tuyến giáp làm tăng tổng hợp và bài tiết $\mathrm{T} 3$ và T4 gây nên các dấu hiệu cường giáp.

Kháng thể ức chế thụ thể của TSH (Thyrotropin Receptor Blocking Antibody: TRBAb). TRBAb có tác dụng ngược lại, gắn vào thụ thể của TSH và ức chế hoạt động chức năng tế bào tuyến giáp. Biểu hiện lâm sàng của bệnh Basedow phụ thuộc vào tỷ lệ $\mathrm{TRSAb} / \mathrm{TRBAb}$, tỷ lệ này càng cao thì triệu chứng lâm sàng càng rõ và ngược lại.

Cả hai loai kháng thể kích thích và ức chế tuyến giáp được gọi chung là kháng thể đối với thụ thể của TSH-TSH receptor antibody (TRAb)[17], [18], [19], [22].

\section{CÁC NGUYÊN NHÂN GÂY VIÊM GAN}

Viêm gan là một khái niệm để chỉ những bệnh gan tiến triển kéo dài nhiều năm do các nguyên nhân khác nhau.

\subsection{Viêm gan mạn tính do virus}

Viêm gan siêu vi là một trong những bệnh truyền nhiễm phổ biến nhất trên thế giới. Bằng kỹ thuật chẩn đoán huyết thanh học và virus học đã cho thấy có các loại viêm gan sau: virus viêm gan $\mathrm{A}$ (HAV), virus viêm gan B (HBV), virus viêm gan $C(\mathrm{HCV})$, virus viêm gan delta (HDV), virus viêm gan E (HEV).

\subsection{Viêm gan mạn do thuốc và nhiễm độc}

Tổn thương gan do thuốc và chất độc có thể từ nhẹ đến nặng và thậm chí là hoại tử gan lan tràn. Thuốc và chất độc có thể gây ra viêm gan cấp, viêm gan mạn, xơ gan và ung thư thể tế bào gan.

Một số thuốc gây viêm gan:Thuốc điều trị tâm thần, thuốc diệt khuẩn (một số kháng sinh và sulfamid), các hormone thuốc chống chuyển hóa (anti-metabolis), thuốc ức chế chức năng tuyến giáp (điều trị Basedow), thuốc gây mê.

Các chất độc công nghiệp: Ethanol, nấm độc, aflatoxin, các Alkaloid thực vật.

\subsection{Viêm gan tự miễn}

So với những bệnh gan khác viêm gan tự miễn là một rối loạn hiếm, tình trạng xảy ra khi hệ thống miễn dịch của bệnh nhân tấn công gan của chính họ gây viêm gan, xơ gan và hoại tử tế bào gan[20].

\section{TỔN THƯONG GAN Ở BÊNNH NHÂN BASEDOW}

Bệnh Basedow là nguyên nhân phổ biến nhất của bệnh cường giáp và chiếm tới $50 \%$ $80 \%$ các trường hợp mắc bệnh cường giáp ở các khu vực khác nhau trên thế giới. Trên lâm sàng, thường quan sát thấy các bất thường về xét nghiệm chức năng gan ở bệnh nhân cường giáp chưa điều trị. Tuy nhiên, tỷ lệ lưu hành báo cáo khác nhau giữa các nghiên cứu khác nhau, dao động từ $37 \%$ dến $78 \%$, [4], [5],[6],[7],[8], [9].

Rối loạn chức năng gan do cường giáp trong Basedow đã được các nhà nghiên cứu đưa ra các giả thuyết khác nhau. Đa số các bất thường của gan chủ yếu được quy cho là do tăng chức năng tuyến giáp. Các yếu tố góp phần vào rối loạn chức năng gan bao gồm các bất thường về gan do cường giáp đơn thuần, tổn thương gan liên quan đến cường giáp với các biến chứng liên quan (ví dụ như suy tim) và bệnh gan đồng thời trong điều trị cường giáp. Trong một nghiên cứu trên mô hình chuột, $\mathrm{T} 3$ dư thừa gây ra rối loạn chức năng gan bằng cách gây ra hiện tượng chết theo trương trình thông qua kích hoạt một con đường phụ thuộc ty lạp thể[13] và hiện tượng chết theo trương trình do cường giáp này liên quan đến việc kích hoạt các con đường mà gây chết các thụ thể trung gian, bao gồm p75[12].

Gần đây, người ta đã chứng minh rằng sự gia tăng của $T R A b$ cũng góp phần gây ra rối loạn chức năng gan ở bệnh nhân mắc Basedow. Tuy nhiên, cho đến nay, cơ chế bệnh sinh chính xác của tổn thương gan trong cường giáp vẫn còn chưa rõvà các dữ liệu chứng minh các yếu tố hoặc các thông số sinh 
hóa góp phần gây ra các bất thường về chức năng gan do Basedow gây ra vẫn còn hạn chế [5], [8], [9].

Hormon kích thích tuyến giáp (TSH) làm vai trò trung gian qua các tương tác đặc hiệu với thụ thể thyrotropin (TSHR). TSHR là một mục tiêu của các kháng thể tự miễn dịch, dẫn đến rối loạn chức năng của tuyến giáp trong nhiều rối loạn tuyến giáp tự miễn dịch, chẳng hạn như Basedow. TSHR mRNA trong các mô gan người được mô tả đầu tiên qua $\mathrm{PCR}$ vào năm 2002[17], [18] và Zhang và cộng sự[21] phát hiện ra rằng TSHR không chỉ hiện diện và hoạt động trong tế bào gan, mà mRNA TSHR ở gan có trình tự giống như của mRNA có nguồn gốc từ tuyến giáp.Do đó TSH ngoài vai trò cổ điển của nó trong việc điều chỉnh chức năng tuyến giáp, còn tác động lên TSHR trong tế bào gan, có thể dẫn đến các bất thường về chức năng gan. Các nghiên cứu tiếp theo là cần thiết để làm sáng tỏ các tác động trực tiếp và cơ chế của TSHR trong tế bào gan trên mô gan và chức năng gan. Ngày nay, nhiều tác giả cho rằng rằng bất thường sinh hóa chức năng gan ở bệnh nhân nhiễm độc giáp chưa điều trị được cho là do tác động chuyển hóa của hormone tuyến giáp dư thừa và tình trạng thiếu oxy mô gan, xảy ra do tăng tiêu thụ oxy và tăng nhu cầu oxy của gan[1],[3]. Trong bệnh Basedow, các bất thường của xét nghiệm chức năng gan không chỉ được quan sát trong tình trạng không được điều trị mà còn được tìm thấy thường xuyên sau khi bắt đầu dùng thuốc kháng giáp tổng hợp. Bất thường sinh hóa gan sau khi dùng propylthiouracil (PTU) được cho là phổ biến hơn. Zhangvà cộng sự (2015) cho rằng các nước khác nhau và dân tộc có thể đóng góp vào sự khác biệt về tỷ lệ bất thường chức năng gan. Bất thường sinh hóa gan sau khi dùng propylthiouracil (PTU) được cho là phổ biến hơn[21].

\section{TÌNH HÌNH NGHIÊN CÚU VỀ RỐI LOAN CHÚC NĂNG GAN Ở BỆNH NHẦN BASEDOW}

Cho đến nay, trên thế giới đã có những nghiên cứu về sự thay đổi chức năng gan với các mức độ tổn thương khác nhau cũng như tìm mối liên quan giữa bất thường chức năng gan với các yếu tố đặc trưng của bệnh Basedow. Tuy vậy, cơ chế hiện vẫn chưa rõ ràng và cần được nghiên cứu nhiều hơn.

Rối loạn chức năng gan ở bệnh nhân cường giáp lần đầu tiên được mô tả bởi Habershon năm 1874. Từ đó, tổn thương hoặc những bất thường về gan ở bệnh nhân cường giáp đã được báo cáo rộng rãi.

Kristen Hull và cộng sự (2007) báo cáo về hai trường hợp vàng da nặng liên quan đến cơn bão tuyến giáp. Kết quả sinh thiết gan cho thấy sự phình to của tế bào gan lan tỏa với ứ mật trong ruột với thâm nhiễm lymphocytic. Cả hai bệnh nhân bị vàng da ứ mật nghiêm trọng trong trường hợp không bị suy tim sung huyết; bệnh gan tiềm ẩn (nhiễm trùng hoặc tự miễn); hoặc tiếp xúc trước đó với thionamides, các chất gây độc cho gan khác, hoặc các loại thuốc bố sung và thay thế. Trong cả hai trường hợp, vàng da đáp ứng với điều trị bằng thuốc antithyroid. Cuối cùng đã được phẫu thuật cắt bỏ tuyến giáp và hết vàng da hoàn toàn. Những dữ liệu này cho thấy ở những bệnh nhân này gợi ý nhiều rối loạn chức năng gan chủ yếu là do cường giáp. Những trường hợp này chỉ ra rằng: sự hiện diện của bilirubin máu cao trong nhiễm độc giáp nặng nên sử dụng thionamides sớm giúp tăng khả năng cứu sống bệnh nhân [23].

K. He và cộng sự (2014)quan sát 236 bệnh nhân Basedow mới được chẩn đoán và chưa điều trị, kết quả là $77,9 \%$ số bệnh nhân có bất thường ít nhất một xét nghiệm chức năng gan. Nồng độ TRAb ở nhóm bệnh nhân có men gan cao là tăng đáng kể so với nhóm bệnh nhân có men gan bình thường. Bệnh nhân có nồng độ $\mathrm{TRAb}$ cao có khả năng phát triển các bất hường sinh hóa gan cao hơn. Tác giả đi đến kết luận: rối loạn chức năng gan là phổ biến ở bệnh nhân mắc Basedow, và tăng TRAb có thể góp phần gây rối loạn chức năng gan ở bệnh nhân mắc Basedow[4].

Castiella. và cộng sự (2015) nghiên cứu về những yếu tố dự báo về bất thường xét nghiệm chức năng gan gây ra bởi Basedow đơn độc. Các bất thường về chức năng gan 
này thường được quan sát thấy ở những bệnh nhân mắc Basedow mới được chẩn đoán và không được điều trị. Trên 289 bệnh nhân thấy $70,9 \%$ trường hợp được phát hiện có ít nhất 1 xét nghiệm chức năng gan bất thường và trong nghiên cứu không tìm thấy bất kỳ sự khác biệt nào về giới tính, tuổi tác và thời gian xuất hiện triệu chứng giữa 2 nhóm. Nghiên cứu đã sử dụng phân tích logistic đa biến, cho thấy bệnh nhân Basedow có mức FT4 và / hoặc TRSA cao có nguy cơ phát triển các bất thường chức năng gan cao hơn.[21]

Gần đây, một nghiên cứu của $\mathrm{He}$ và cộng sự đã chứng minh rằng nồng độ $\mathrm{TRAb}$ tăng cao có thể góp phần gây ra rối loạn chức năng gan ở bệnh nhân mắc Basedow. Tuy nhiên trong các nghiên cứu này, mối liên quan giữa các chỉ số chức năng tuyến giáp và tổn thương gan vẫn còn gây tranh cãi. Cho đến nay, các dữ liệu chứng minh các yếu tố hoặc các thông số sinh hóa góp phần gây ra các bất thường về chức năng gan do Basedow gây ra vẫn còn hạn chế [4].

Ở Việt Nam chưa có công trình nghiên cứu nào về bất thường chức năng gan ở bệnh nhân Basedow chưa điều trị

\section{KẾT LUẬN}

Trên thực tế lâm sàng, tăng men gan ở bệnh nhân Basedow khi mới phát hiện và chưa điều trị bệnh gặp khá phổ biến với các mức độ tăng men gan khác nhau. Tăng men gan là yếu tố quan trọngliên quan đến quá trình điều trị bệnh, liều thuốc được chỉ định,theo dõi bệnh và sự cần thiết phải loại trừ những bệnh liên quan có thể gây tổn thương gan dẫn đến hủy hoại tế bào gan trước khi điều trị Basedow.

Hiện nay, nhiều tác giả đã tiến hành các nghiên cứu in vitro và in vivo, cả động vật và ở người và đưa ra các giả thuyết về cơ chế khác nhau của bất thường sinh hóa chức năng gan ở bệnh nhân nhiễm độc giáp chưa điều trị. Trong đó cơ chế do tác động chuyển hóa của hormone tuyến giáp dư thừa và tình trạng thiếu oxy mô gan, xảy ra do tăng tiêu thụ oxy và tăng nhu cầu oxy của gan được nhiều tác giả đồng thuận nhất.Gần đây, người ta đã chứng minh rằng sự gia tăng của $T R A b$ cũng góp phần gây ra rối loạn chức năng gan ở bệnh nhân mắc Basedow và sự hiện diện của Bilirubin máu cao trong nhiễm độc giáp nặng nên sử dụng thionamides sớm giúp tăng khả năng cứu sống bệnh nhân.

Tuy nhiên, các dữ liệu chứng minh các yếu tố hoặc các thông số sinh hóa góp phần gây ra các bất thường về chức năng gan do Basedow gây ra vẫn còn hạn chế. Do đó, các nghiên cứu tiếp theo là cần thiết để làm sáng tỏ cơ chế tác động trực tiếp và mối liên quan giữa các yếu tố đặc trưng của bệnh Basedowvới các yếu tố trong tế bào gan, trên mô gan và chức năng gan.

\section{TÀI LIÊU THAM KHẢO}

1. Nguyễn Hải Thủy (2015): "Bệnh Basedow" Bệnh nội tiết chuyển hóa, Nhà xuất bản giáo dục Việt Nam, Tr 195-223

2. Đại học y Hà nội, "Bài giảng hóa sinh", 2003, Nxb Y học, trang 276-290

3. Brent GA. Clinical practice. Graves' disease. N Engl J Med 2008; 358:25942605.

4. $\mathrm{He} \mathrm{K}, \mathrm{Hu} \mathrm{Y}, \mathrm{Xu} \mathrm{XH}$, et al. Hepatic dysfunction related to thyrotropin receptor antibody in patients with Graves' disease. Exp Clin Endocrinol Diabetes 2014; 122:368-372.

5. Huang MJ, Li KL, Wei JS, et al. Sequential liver and bone biochemical changes in hyperthyroidism: prospective controlled follow-up study. Am J Gastroenterol 1994; 89:1071-1076

6. Kubota S, Amino N, Matsumoto Y, et al. Serial changes in liver function tests in patients with thyrotoxicosis induced by Graves' disease and painless thyroiditis. Thyroid 2008; 18:283-287.

7. Biscoveanu M, Hasinski S. Abnormal results of liver function tests in patients with Graves' disease. Endocr Pract 2000; 6:367-369.

8. Khemichian S, Fong TL. Hepatic dysfunction in hyperthyroidism. 
Gastroenterol Hepatol (NY) 2011; 7:337-339.

9. Cui B, Abe M, Hidata $S$, et al. Autoimmune hepatitis associated with Graves' disease. Intern Med 2003; 42:331-335.

10. de Campos Mazo DF, de Vasconcelos GB, Pereira MA, et al. Clinical spectrum and therapeutic approach to hepatocellular injury in patients with hyperthyroidism. Clin Exp Gastroenterol 2013; 6:9-17.

11. Kumar A, Sinha RA, Tiwari M, et al. Hyperthyroidism induces apoptosis in rat liver through activation of death receptormediated pathways. J Hepatol 2007; 46:888-898.
12. Lewis E. Braverman, Robert D. Utiger (2002), "Introduction to thyrotoxicosis", The thyroid a fundamental and clinical, text eighth edition, part IV, section A, pp. $515-517$

13. Agustin Castiella, Ruiguo Zhang Ruiguo Zhang, MD, Xun Tian, MD, et al (2015), " Factors Predicting Abnormal Liver Function Tests. Induced by Graves' Disease Alone" Medicine (Baltimore) 42:270-278.

14. Kristen Hull, Richard Horenstein, Rosalie Naglieri, Kashif Munir. et al. (2007) "Two cases of thyroid storm-associated cholestatic jaundice" Endocrin Practic; 13(5):476-80. 